\title{
Pendidikan kecakapan hidup dalam mewujudkan kemandirian warga binaan eks psikotik
}

\author{
Indah Maghfiroh \\ Magister Psikologi, Program Pascasarjana, Universitas Ahmad Dahlan \\ aghfira95@gmail.com
}

\author{
Zainal Arifin \\ Ilmu Tarbiyah dan Keguruan UIN Sunan Kalijaga \\ zainal.arifin@uin-suka.ac.id
}

\begin{abstract}
ABSTRAK
Penelitian ini bertujuan untuk mengetahui sistem dan hasil pengelolaan proses pendidikan kecakapan hidup yang dilakukan pengelola pendidikan dalam mewujudkan kemandirian warga binaan eks psikotik yang dilaksanakan di Lembaga Sosial Hafara Kasihan, Bantul, Yogyakarta. Penelitian ini merupakan penelitian kualitatif. Teknik pengumpulan data dilakukan melalui observasi nonpartisipatif (nonparticipant observation), wawancara mendalam (in depth interview) dan dokumentasi. Teknik penentuan validitas dan keabsahan data dengan cara triangulasi sumber dan triangulasi teknik. Temuan penelitian ini meliputi; pertama, sistem pelaksanaan pendidikan ditempuh melalui empat tahapan: a. Perencanaan (planing) dengan menetapkan tujuan, menentukan pendamping, pengelompokan warga binaan, perumusan strategi, menentukan jenis keterampilan, dan menentukan metode. b. Pengorganisasian (organizing) meliputi: membentuk struktur organisasi atau kepengurusan, merumuskan serta menetapkan pembagian tugas dan wewenang pada tiap kesatuan atau unit. c. Penggerakkan (actuacting) dilakukan dengan cara memberikan motivasi, dan menjalin hubungan komunikasi. d. Pengawasan (controlling) ditempuh melalui; penetapan standar, evaluasi, mengadakan tidakan-tindakan perbaikan. Kedua, hasil pengelolaan pendidikan kecakapan hidup dalam mewujudkan kemandirian bagi warga binaan meliputi: a. kemandirian mengurus diri sendiri. b. kemandirian dalam bersosialisasi.
\end{abstract}

Kata Kunci: Eks Psikotik, Kemandirian, Pendidikan Kecakapan Hidup, Warga Binaan Bullying

\begin{abstract}
This study aims to determining the systems and results of life skills education management processes carried out by educational managers in realizing independence of ex-psychotic fostered citizens conducted at the Hafara Kasihan Social Institute, Bantul, Yogyakarta. This research is a qualitative research. Data collection techniques carried out through non-participatory observation, in-depth interviews and documentation. The technique of determining the validity and validity of the data is by triangulation of sources and triangulation of techniques. The findings of this study include; first, the education implementation system is pursue through four stages; a. Planning is carry out by setting skills education goals, determining skills education companions, grouping fostered citizens, formulating strategies, determining the types of skills, and determining methods. b. Organizing includes; set up organizational structure or management, formulate and find the divisions of tasks and authority in each unit or unit. $c$. Activation has done by way of; giving a boost, and setting up a communication relationships. $d$. Supervision (controlling) was going through by setting standards, evaluating, and carrying out corrective actions. Second, the results of skills education management in realizing independence for fostered citizens include: $a$. independence to take care of yourself. $b$. independence in socializing.
\end{abstract}

Keywords: Ex-Psychotic, Fostered Citizens, Life Skills Education, Independence

Indah Maghfiroh,email: aghfira95@gmail.com 
Jurnal Psikologi Terapan dan Pendidikan

ISSN: $2715-2456$

Vol. 1, No. 2, November 2019, pp. 117-127

\section{PENDAHULUAN}

Pendidikan merupakan proses yang harus dilaksanakan secara terus menerus dan tidak pernah berakhir, karena pendidikan sebagai kunci utama untuk mencetak generasi bangsa yang unggul (Asmani, 2009). Tirtarahardja dan Sula (2000) memaparkan bahwa sasaran pendidikan adalah manusia. Pendidikan bermaksud membantu peserta didik untuk menumbuh kembangkan potensi-potensi kemanusiaannya. Pendidikan tidak hanya terdapat di sekolah saja, sejak lahir berada di keluarga sudah dapat disebut sebagai pendidikan. Selain pendidikan di sekolah ada pula pendidikan nonformal, menurut John Dewey dalam Tirtarahadja dan Sula (2000) mengemukakan pentingnya pendidikan, karena berdasarkan atas tiga pokok pemikiran, yaitu: (1) pendidikan merupakan kebutuhan untuk hidup, (2) pendidikan sebagai pertumbuhan, dan (3) pendidikan sebagai fungsi sosial. Pendidikan nonformal adalah salah satu solusi pemerataan pendidikan bagi kalangan menengah kebawah yang tidak mampu mengenyam pendidikan formal karena permasalahan ekonomi (Patriana, 2013). Pendidikan nonformal sangatlah dibutuhkan untuk meningkatkan kualitas sumber daya manusia terutama pada mereka yang selama ini kurang mendapatkan perhatian seperti masyarakat yang tinggal di daerah terpencil, anak jalanan, serta masyarakat yang kurang mampu. Dengan demikian, pendidikan diberikan untuk semua kalangan tidak memandang usia, pangkat, jabatan, maupun kedudukan (education for all) (Krisna, 2014).

Menurut Undang-undang Sisdiknas No. 20 Tahun 2003 pasal 26 program pendidikan nonformal meliputi pendidikan kecakapan hidup, pendidikan anak usia dini, pendidikan kepemudaan, pendidikan pemberdayaan perempuan, pendidikan keaksaraan, pendidikan keterampilan dan pelatihan kerja, pendidikan kesetaraan serta pendidikan lain yang ditujukan untuk mengembangkan kemampuan peserta didik. Pendidikan kecakapan hidup (life skills) adalah "pendidikan yang memberikan kecakapan personal, kecakapan sosial, dan kecakapan vokasional untuk bekerja atau usaha mandiri.” Kecakapan hidup (life skills) dapat pula diartikan sebagai kecakapan yang dimiliki seseorang untuk mau dan berani menghadapi problema hidup dan penghidupan secara wajar tanpa merasa tertekan, kemudian secara proaktif dan kreatif mencari serta menemukan solusi sehingga akhirnya mampu mengatasinya (Depdiknas, 2003). Lembaga sosial untuk menciptakan sumberdaya manusia yang produktif seharusnya dapat menerapkan pendidikan kecakapan hidup (life skills) sebagai jalan mewujudkan sumber daya manusia yang lebih baik. Hal ini didukung oleh penelitian Noor (2015) yang menunjukkan bahwa sistem pendidikan dan proses pembelajaran pada dasarnya merupakan model pendidikan kecakapan hidup. Peserta didik belajar dan dilatih untuk memecahkan dan mengatasi berbagai kesulitan yang dihadapinya secara mandiri. Hasil pembelajaran menunjukkan adanya peningkatan dalam aspek pengetahuan, keterampilan dan sikap 
Jurnal Psikologi Terapan dan Pendidikan

ISSN: $2715-2456$

Vol. 1, No. 2, November 2019, pp. 117-127

terhadap kemandirian. Penelitian yang dilakukan Mirza, Yunior dan Novita (2019) juga mengatakan bahwa pelatihan kecakapan hidup berpengaruh positif dan signifikan terhadap penumbuhan wirausaha baru.

Permasalahan yang sering terjadi di masyarakat meliputi keterbatasan ekonomi ataupun putus sekolah menjadi problematika sebagian besar kalangan menengah kebawah, seperti gelandangan dan pengemis terutama di kota-kota besar termasuk Yogyakarta. Hal ini menjadi sebuah problematika yang akan mengganggu ketertiban dan keamanan masyarakat, sehingga menjadi sebuah persoalan karena secara tidak langsung akan menghambat perkembangan suatu bangsa. Permasalahan gelandangan, pengemis, pengamen maupun pemulung tidak bisa didiamkan begitu saja, namun harus ditanggulangi, baik oleh pemerintah ataupun masyarakat itu sendiri (Priyantoro, 2015). Pendidikan kecakapan hidup (life skills) diharapkan mampu menjadi solusi permasalahan merebaknya gelandangan, pengemis, pengamen, serta pemulung. Hal tersebut merupakan fenomena sosial yang tidak bisa dihindari keberadaannya dalam lingkungan sosial masyarakat, khususnya yang berada di daerah perkotaan. Salah satu faktor timbulnya gelandangan, pengemis, pengamen, dan pemulung adalah faktor kemiskinan. Selain faktor kemiskinan adapula faktor lain yaitu terbatasnya lapangan pekerjaan, serta terbatasnya pengetahuan dan keterampilan, sehingga mereka terpaksa menjadi gelandangan, pengemis, pengamen maupun pemulung untuk mempertahankan hidup. Konsep belajar sepanjang hayat pada pendidikan kecakapan hidup diharapkan mendorong motivasi masyarakat untuk terus belajar dimanapun mereka berada dan dalam kondisi apapun, tidak mengenal adanya gender ataupun batas usia dalam belajar (Kamil, 2007). Pendidikan kecakapan hidup yang selenggarakan Lembaga Sosial Hafara sebagai alternatif agar dapat mendampingi dan membina masyarakat yang memiliki perhatian khusus agar mereka dapat hidup mandiri. Keterampilan yang diberikan kepada warga binan adalah keterampilan fisik, bekal keterampilan seperti; budidaya ikan, pembuatan batako, dan pembuatan kerajinan tangan serta berkebun, diharapkan dapat meningkatkan kualitas sumber daya manusia.

Warga binaan yang tinggal di Lembaga Sosial Hafara adalah gelandangan yang mengalami eks psikotik. Oleh karena itu peneliti tertarik melakukan penelitian dengan tujuan mengetahui sistem dan hasil pegelolaan proses pendidikan kecakapan hidup yang dilakukan pengelola pendidikan dalam mewujudkan kemandirian warga binaan eks psikotik yang dilaksanakan di Lembaga Sosial Hafara Kasihan, Bantul, Yogyakarta.

\section{METODE PENELITIAN}

Penelitian ini menggunakan pendekatan kualitatif deskriptif. Penelitian ini didesain dengan pendekatan kualitatif yaitu suatu penelitian yang dilakukan untuk memaparkan serta menganalisis fenomena ataupun peristiwa serta aktivitas sosial baik secara individual maupun kelompok (Sukmadinata, 
Jurnal Psikologi Terapan dan Pendidikan

ISSN: $2715-2456$

Vol. 1, No. 2, November 2019, pp. 117-127

2010). Dalam hal ini peneliti mengamati dan mendeskripsikan fenomena di Lembaga Sosial Hafara. Teknik dan alat pengumpul data meliputi observasi nonpartisipatif, wawancara mendalam (indepth interview), dan dokumentasi. Analisis data dilakukan melalui beberapa tahap, yaitu: reduksi data, penyajikan data, dan penarikan kesimpulan.

Sedangkan sumber data penelitian, peneliti menggunakan teknik purposive sampling. Menurut Sugiyono (2017), teknik purposive sampling adalah teknik pengambilan sampel sumber data dengan pertimbangan tertentu. Maksud dari pertimbangan tertentu ini adalah orang yang dianggap paling mengetahui apa yang diteliti. Sampel dalam penelitian ini datanya adalah orang yang memiliki kualifikasi mengetahui, mamahami, dan mengalami dalam proses pengelolaan kegiatan keterampilan meliputi pembina, pengelola bidang pendidikan kecakapan hidup, pendamping dan warga binaan Lembaga Sosial Hafara.

Teknik penentuan validitas dan keabsahan data menggunakan triangulasi tektik dan triangulasi sumber. Triangulasi teknik berarti peneliti menggunakan teknik pengumpulan data yang berbeda-beda untuk mengecek data dari sumber yang sama. Sedangkan triangulasi sumber dilakukan untuk mendapatkan data dari sumber yang berbeda-beda dengan teknik yang sama (Sugiyono, 2017). Data yang peneliti dapatkan dari triangulasi teknik ini berupa catatan lapangan pada saat observasi dan data dokumentasi. Sedangkan triangulasi sumber telah dilakukan peneliti ketika melakukan pengumpulan data dengan metode wawancara, yaitu ketika wawancara kepada pengelola, pendamping, pembina, dan warga binaan Lembaga Sosial Hafara.

\section{HASIL DAN PEMBAHASAN}

\section{Proses Pelaksanaan Pendidikan Kecakapan Hidup}

Berdasarkan hasil penelitian, pendidikan kecakapan hidup di Lembaga Sosial Hafara Kasihan, Bantul, Yogyakarta dilakukan secara mandiri yaitu pendamping dan pengelola belajar secara otodidak. Peserta didik dalam pendidikan keterampilan adalah para pasca gelandangan dimana mereka mengalami eks psikotik. Menurut Sundari (2005) psikotik adalah gangguan jiwa yang ditandai dengan ketidakmampuan individu menilai kenyataan yang terjadi, misalnya terdapat halusinasi, waham dan perilaku kacau atau aneh.

Adapun proses pengelolaan pendidikan keterampilan di Lembaga Sosial Hafara menggunakan empat fungsi manajemen menurut G.R Terry, yaitu perencanaan (planning), pengorganisasian (organizing), penggerakkan (actuacting) dan pengawasan (controlling). 
Jurnal Psikologi Terapan dan Pendidikan

ISSN: $2715-2456$

Vol. 1, No. 2, November 2019, pp. 117-127

\section{Perencanaan (planning)}

Proses perencanaan yang dilakukan Lembaga Sosial Hafara yaitu pertama, menetapkan tujuan yang meliputi melatih kemandirian, menambah pendapatan, sebagai bekal keterampilan, sebagai media terapi. Kedua, menentukan pendamping. Pendamping pendidikan kecakapan hidup ini meliputi para pekerja sosial yang bertugas memberikan arahan-arahan dalam memudahkan pelaksanaan kegiatan keterampilan. Pendamping juga memiliki tanggung jawab mengarahkan dan mengawasi dalam proses kegiatan keterampilan. Ketiga, pengelompokan warga binaan. Peserta didik yang mengikuti pendidikan keterampilan adalah para warga binaan kelas satu dan kelas dua, sedangkan kelas nol belum mengikuti kegiatan keterampilan. Keempat, menetapkan strategi. Adapun strategi yang digunakan kegiatan keterampilan adalah dengan membagi kelas-kelas untuk dipisahkan berdasarkan tingkat gangguan jiwa yang mereka alami. Kelima, menentukan jenis keterampilan. Untuk jenis keterampilannya adalah keterampilan berkebun, budidaya ikan, pembuatan batako, kerajianan tangan seperti pembuatan bros, pin, gantungan kunci. Keenam, menentukan metode. Metode yang digunakan adalah metode demonstrasi yaitu memberikan materi dengan memperagakannya secara langsung di depan warga binaan.

\section{Pengorganisasian (organizing)}

Pengorganisasian mempunyai arti penting, sebab dengan pengorganisasian dapat memudahkan tugas-tugas pengelola pendidikan kecakapan hidup. Pembagian tugas ini yang menangani adalah pembina, pimpinan, sekretaris, bendahara, serta sebagian pekerja sosial yang bertugas sebagai pendamping. Pengorganisasisan Lembaga Sosial Hafara dilakukan dengan membentuk struktur organisasi atau kepengurusan, serta merumuskan dan menetapkan pembagian tugas dan wewenang pada tiap kesatuan atau unit. Setiap kegiatan, pengelola menjalankan kerjasama tim dalam menyelesaikan sebuah kegiatan, serta laporan kegiatan apabila suatu kegiatan tersebut telah dilaksanakan. Pengorganisasian Lembaga Sosial Hafara meliputi, membentuk struktur organisasi atau kepengurusan dan merumuskan serta menetapkan pembagian tugas dan wewenang pada tiap kesatuan atau unit.

\section{Penggerakkan (actuacting)}

Proses menggerakan yang di jalankan di Lembaga Sosial Hafara yaitu dengan memberikan motivasi dan menjalin hubungan komunikasi. Motivasi dilakukan dengan memberikan masukan terhadap hasil evaluasi dari masing-masing tugas yang dijalankan di bidangnya. Pemberian motivasi ini bertujuan agar para pengelola dan pendamping kegiatan keterampilan dapat bekerja secara profesional. Sehingga keterampilan yang diterapkan dapat lebih berkembang dengan baik. Pemberian motivasi dalam penyelenggaraan pendidikan kecakapan hidup, berarti usaha menumbuhkan keinginan yang terdapat pada pengelola, pendamping ataupun warga binaan agar mereka dapat menjalankan tugasnya. Pembina Lembaga 
Jurnal Psikologi Terapan dan Pendidikan

ISSN: $2715-2456$

Vol. 1, No. 2, November 2019, pp. 117-127

Sosial Hafara memberikan motivasi kepada para pendamping dan pengelola dalam menjalankan tugasnya, sedangkan para warga binaan diberikan motivasi dari para pendamping, karena pendampilanglah yang secara langsung berinteraksi dengan warga binaan setiap harinya.

Setelah para pengelola kegiatan keterampilan dimotivasi, maka perlu dibimbing dan diarahkan agar pekerjaan yang mereka kerjakan sesuai dengan ketentuan, sehingga dapat mengarahkan pada pencapaian tujuan dan sasaran secara efektif dan efisien. Pemberian motivasi yang di berikan oleh pembina Lembaga Sosial Hafara yaitu dengan terus menasehati pengelola ataupun pendamping bahwa tugas yang mereka kerjakan di Lembaga Sosial Hafara jangan diukur semata-mata karena materi atau gaji yang diberikan, tetapi harus ikhlas membantu orang-orang yang membutuhkan di Lembaga Sosial Hafara.

Komunikasi yang efektif merupakan penentu kesuksesan. Adanya orang-orang yang terhimpun dalam suatu organisasi, tak dapat bekerjasama dengan baik tanpa adanya komunikasi yang baik diantara pihak atasan dengan bawahan atau pihak bawahan itu sendiri. Menggerakkan dan menjaga hubungan serta membina komunikasi yang baik antara para pengurus adalah suatu hal yang harus dilaksanakan tanpa memandang adanya status dan jabatan dalam kesatuan atau unit-unit dalam kerja. Dengan menjalin hubungan antar pengelola akan tercipta sebuah kebersamaan dan jalinan kerja yang harmonis sehingga dapat menghantarkan kepada pencapaian tujuan dan sasaran yang telah ditetapkan. Saat peneliti melakukan observasi, adanya hubungan yang harmonis baik antar pengurus, sesama warga binaan, maupun warga binaan dengan pengurus, begitupula pimpinan ataupun pembina, mereka menjalin hubungan kekeluargaan yang baik, tidak membeda-bedakan status ataupun jabatan, mereka telah menganggap satu sama lain sebagai bagian dari keluarga mereka.

\section{Pengawasan (controlling)}

Proses pengawasan Lembaga Sosial Hafara meliputi; pertama, penetapan standar. Standar keberhasilan yang digunakan dalam pelaksanaan pendidikan kecakapan hidup ini adalah diukur melalui bagaimana kegiatan yang dijalankan tersebut dapat berjalan dalam jangka waktu yang lama. Kedua, evaluasi. Evaluasi yang dilaksanakan Lembaga Sosial Hafara adalah satu bulan sekali masing-masing bidang memiliki laporan secara tertulis dan ketika salah satu bidang memiliki masalah, akan dibicarakan diforum tersebut. Jika memiliki permasalahan maka akan dipecahkan secara musyawarah. Ketiga, mengadakan tindakan-tindakan perbaikan, dalam hal ini Lembaga Sosial Hafara melakukan tindakan perbaikan dari hasil evaluasi, sehingga dapat memberikan solusi terhadap kendala-kendala yang ada.

\section{Hasil Pendidikan Kecakapan Hidup}

Hasil pendidikan kecakapan hidup dalam mewujudkan kemandirian pada warga binaannya sendiri memiliki hasil positif bagi warga binaan, karena dapat mewujudkan kemandirian. Kemandirian yang 
Jurnal Psikologi Terapan dan Pendidikan

ISSN: $2715-2456$

Vol. 1, No. 2, November 2019, pp. 117-127

berasal dari kata "autonomy" yang diartikan sebagai suatu kondisi di mana seorang tidak tergantung pada orang lain dalam menentukan keputusan dan adanya sikap kepercayaan diri. Steinberg (1995), mengkonsepsikan kemandirian sebagai self governing person, yakni kemampuan menguasai diri sendiri. Dari lima puluh lima warga binaan yang mengikuti kegiatan keterampilan, empat puluh orang sudah dapat dikatakan mandiri yang sebelumnya mereka hanya di jalan menggelandang tanpa tujuan yang jelas, sekarang mereka dapat melakukan aktivitas sehari-hari seperti layaknya orang normal. Kemandirian yang didapatkan tersebut meliputi: 1.) Kemandirian mengurus diri sendiri. Warga binaan di Lembaga Sosial Hafara adalah orang yang mengalami suatu keadaan kelainan jiwa, mereka bergabung di dalam panti, dan sedang dalam proses rehabilitasi. Pendidikan kecakapan hidup ini merupakan salah satu program di Lembaga Sosial Hafara agar para warga binaan dapat kembali hidup normal baik di lingkungan keluarga ataupun di lingkungan masyarakat. Salah satu hasil dari diadakannya kegiatan keterampilan adalah menjadikan warga binaan madiri dalam mengurus dirinya sendiri seperti dapat melakukan mandi sendiri, pakai baju sendiri, makan sendiri dan lain sebagainya. Karena penyandang eks gangguan jiwa sebagai individu pada hakekatnya masih mempunyai potensi yang dapat dikembangkan, untuk itu dengan diadakannya program keterampilan ini, diharapkan agar warga binaan yang mengalami eks gangguan jiwa dapat pulih kembali layaknya orang normal. Hal tersebut tidak lepas dari peran aktif para pendamping yang senantiasa mengasuh dan memberikan bekal keterampilan kepada para warga binaan. Satori (2002), menegaskan kecakapan hidup memiliki arti yang lebih luas dari sekedar keterampilan vokasional atau keterampilan untuk bekerja. kecakapan hidup (life skills) pada dasarnya adalah kemampuan seseorang untuk berjuang berani hidup (survival).

Menurut penuturan salah satu pengelola kegiatan keterampilan mengemukakan, bahwa kegiatan keterampilan ini dapat dijadikan sebagai media terapi untuk penyandang eks ganguan jiwa karena dengan diadakannya kegiatan keterampilan ini memicu warga binaan untuk dapat menjalankan aktivitas serta dapat menjalankan otak kanan dan kirinya dalam berfikir, selain itu kegiatan keterampilan ini mengajarkan untuk bersosialisasi sehingga melalui proses tersebut warga binaan dapat kembali normal secara perlahan-lahan. Warga binaan yang mengalami eks gangguan jiwa memerlukan metode khusus untuk menerapkan kegiatan keterampilan yaitu dengan diberikan arahan sesuai kemampuan yang dimiliki para warga binaan. Berdasarkan wawancara dan observasi, kegiatan keterampilan ini secara tidak langsung melatih para warga binaan untuk dapat menjalankan aktifitas sehari-hari karena kegiatan keterampilan yang dijalankannya pun merupakan jenis keterampilan kecakapan hidup seperti beternak dan berkebun. Menurut penuturan Desi Suryani, bahwa makna kemandirian untuk para warga binaan yang mengalami eks psikotik berbeda dengan kemandirian untuk orang normal pada umumnya. Jika orang normal pada umumnya dikatakan bisa mandiri 
Jurnal Psikologi Terapan dan Pendidikan

ISSN: $2715-2456$

Vol. 1, No. 2, November 2019, pp. 117-127

kalau mereka sudah dapat mencukupi kebutuhan hidupnya sendiri dengan bekerja dan tidak lagi kembali ke jalanan. Sedangkan makna kemandirian untuk orang yang mengalami eks psikotik itu bisa dikatakan mandiri jika mereka sudah dapat mengerjakan aktivitas layaknya orang normal seperti bisa makan sendiri, mandi sendiri, memakai baju sendiri, minum obat sendiri dan sebagainya. Bruner (1960), Sanjaya (2008), dan Hidayat (2013) menegaskan keterampilan hidup bukan sekedar keterampilan manual dan bukan pula keterampilan untuk bekerja, tetapi suatu keterampilan untuk hidup yang dapat dipilah menjadi lima kategori, yaitu: (1) Keterampilan mengenal diri sendiri atau self awareness dan keterampilan personal atau personal skill; (2) Keterampilan berpikir rasional atau thinking skill; (3) Keterampilan sosial atau social skill; (4) Keterampilan akademik atau academic skill; dan (5) Keterampilan vokasional atau vocational skill. Setelah mereka dapat menjalankan aktivitas layaknya orang normal, para warga binaan yang mengalami eks ganggua jiwa dilatih secara perlahan-lahan untuk mengikuti kegiatan keterampilan. Menurut pengelola dan pendamping, kegiatan keterampilan dapat mempengaruhi perkembangan yang baik bagi mereka, dan dapat merangsang otak kanan dan otak kiri mereka untuk berfikir. Sebelum warga binaan mengikuti kegiatan keterampilan, para warga binaan cenderung tidak memiliki bekal untuk menjalankan kehidupannya, bahkan merekapun untuk melakukan aktivitas sehari-hari seperti makan, mandi, memakai baju dan lain sebagainya harus dibantu oleh pendamping. Disini pendamping memiliki peran yang sangat penting untuk perkembangan diri mereka agar lebih baik. Hal tersebut selaras dengan Dimyati \& Mudjiono (2009) bahwa perhatian mempunyai peranan yang penting dalam kegiatan belajar. Prinsip-prinsip pembelajaran berkaitan dengan perhatian dan motivasi, keaktifan, keterlibatan langsung atau berpengalaman, pengulangan, tantangan, balikan dan penguatan, serta perbedaan individual. Kegiatan keterampilan ini bukan hanya untuk menambah wawasan bagi warga binaan tetapi juga untuk perkembangan kesehatan mental, dimana para warga binaan melakukan kegitan keterampilan agar dapat selalu memberikan gerakan dari akalnya dan juga dapat melakukan kegiatan yang bermanfaat yang mana mereka pada awalnya masih belum dapat mengerjakannya secara mandiri tetapi sekarang sudah dapat mengerjakannya secara mandiri. 2.) Kemandirian dalam bersosialisasi. Sosialisasi pada dasarnya merupakan proses terintegrasinya individu ke dalam kehidupan bermasyarakat sebagai makhluk biologis menjadi makhluk sosial. Oleh karena itu kehidupan masyarakat mempunyai aturan berupa nilai dan norma sosial. Maka agar individu dapat berinteraksi dengan baik, dia perlu mengerti dan memahami nilai dan norma sosial sebagai pedoman perilakunya dalam kehidupan bermasyarakat. Untuk dapat mengerti dan memahami nilai dan norma tersebut, individu perlu mempelajarinya, sehingga proses sosialisasi sering kali disebut dengan proses belajar untuk hidup bermasyarakat. Menurut Wahyudin (2017), keterampilan sosial 
Jurnal Psikologi Terapan dan Pendidikan

ISSN: $2715-2456$

Vol. 1, No. 2, November 2019, pp. 117-127

atau keterampilan interpersonal meliputi keterampilan berkomunikasi, keterampilan bekerja sama untuk menumbuhkan hubungan yang harmonis antara individu yang satu dengan individu lainnya.

Proses sosialisasi tidak selalu dapat berjalan lancar karena adanya sejumlah kesulitan seperti kesulitan dalam berkomunikasi yang dialami individu ketika ia tidak mengerti apa yang diharapkan dari padanya, atau tidak mengetahui apa yang diinginkan oleh masyarakat atau tuntutan kebudayaan tentang kelakuannya. Manusia lahir dalam keadaan tidak berdaya dan keadaan ini menyebabkan ketergantungan pada orang lain. Begitupun dengan para warga binaan eks psikotik yang memerlukan bantuan orang lain untuk mengembangkan dirinya agar dapat hidup layaknya kemandirian yang dimiliki orang normal. Warga binaan di Lembaga Sosial Hafara ini memerlukan bimbingan yang tepat agar mereka dapat bersosialisasi terutama dalam hal mengurus dirinya sendiri sehingga tidak selalu menggantungkan dirinya pada orang lain. Oleh karena itu, kegiatan keterampilan ini memberikan manfaat untuk warga binaan agar dapat bersosialisasi dengan lingkungan sekitar. Misalnya, sebelum pembuatan kerajinan tangan dimulai, para pendamping menyuruh warga binaan terlebih dahulu untuk memperkenalkan identitas dirinya dengan menyebutkan nama dirinya. Dari hal tersebut, maka dapat memudahkan mereka untuk berkomunikasi satu sama lain. Dalam proses kegiatan keterampilan ini, warga binaan dilatih untuk dapat berkomunikasi dengan sesama warga binaan yang mengikuti keterampilan, selain itu pendamping kegiatan keterampilan juga terus memantau dan membimbing kepada para warga binaan dengan memberikan perhatian dan motivasi, sehingga dapat memicu lahirnya motivasi diri warga binaan dalam menjalin hubungan komunikasi disekitar lingkungannya. Hal ini dipertegas oleh Anwar (2004) mengemukakan bahwa motivasi orang yang mau belajar yaitu: (a) motivasi intrinsik, timbul dari setiap individu seperti kebutuhan, bakat, kemauan, minat dan harapan yang terdapat pada diri seseorang (b) motivasi ekstrinsik timbul dari luar individu yang muncul karena adanya ransangan (simulus) dari luar lingkungannya. Sihombing (2000) juga menyatakan bahwa orang mau belajar karena menginginkan perbaikan hidup pada dirinya.

\section{KESIMPULAN}

Berdasarkan hasil penelitian dan pembahasan diatas, maka peneliti dapat menyimpulkan sebagai berikut: 1.) Sistem pelaksanaan pendidikan kecakapan hidup di Lembaga Sosial Hafara ditempuh melalui 4 (empat) tahapan meliputi: a.) Perencanaan (planning) Perencanaan (planning) ditempuh dengan menetapkan tujuan, menentukan pendamping, pengelompokan warga binaan, perumusan strategi, menentukan jenis keterampilan, dan menentukan metode. b.) Pengorganisasian (organizing) Pengorganisasian (organizing) dengan membentuk struktur organisasi atau kepengurusan, merumuskan serta menetapkan pembagian tugas dan wewenang pada tiap kesatuan atau unit. c.) Penggerakkan 
Jurnal Psikologi Terapan dan Pendidikan

ISSN: $2715-2456$

Vol. 1, No. 2, November 2019, pp. 117-127

(actuacting) Penggerakan dilakukan dengan cara memberikan motivasi, dan menjalin hubungan komunikasi. d.) Pengawasan (controlling) Pengawasan (controlling) ditempuh melalui penetapan standar, evaluasi, mengadakan tidakan-tindakan perbaikan. Selanjutnya yaitu 2.) Hasil pengelolaan pendidikan kecakapan hidup dalam mewujudkan kemandirian bagi warga binaan meliputi: a.) Kemandirian mengurus diri sendiri. Warga binaan yang mengalami eks psikotik sudah dapat dikatakan mandiri ketika mereka sudah dapat menjalankan aktivitasnya seperti layaknya orang normal pada umumnya seperti dapat mandi sendiri, makan sendiri, minum obat sendiri, memakai baju sendiri dan lain sebagainya. b.) Kemandirian dalam bersosialisasi. Kemandirian dalam bersosialisasi, warga binaan dapat melakukan interaksi dan komunikasi terhadap individu-individu yang berada di lingkungan Lembaga Sosial Hafara.

\section{DAFTAR PUSTAKA}

Anwar. (2004). Pendidikan kecakapan hidup (life skills education). Bandung: Alfabeta.

Asmani, J.M. (2009). Manajemen pengelolaan dan kepemimpinan pendidikan profesional. Yogyakarta: Diva Press.

Bruner. (1960). The Process of Education. New York: Vintage Books.

Depdiknas. (2003). Pedoman penyelenggaraan program kecakapan hidup (Life Skills) PLS. Jakarta: Ditjen PLSP, Depdiknas.

Dimyati \& Mudjiono. (2009). Belajar dan pembelajaran. Jakarta: Rineka Cipta.

Hidayat. (2013). Penggembangan kurikulum baru. Bandung: PT Remaja Rosdakarya

Kamil. (2007).” Tenaga Pendidik Pendidikan Nonformal dalam Membangun Kemandirian Warga Belajar”. Jurnal Ilmiah Visi, 2(2), 12-20.

Krisna,F.N.(2014)."Studi Kasus Layanan Pendidikan Nonformal Suku Baduy”. Jurnal Pendidikan dan Kebudayaan, 20(1).

Mirza, D.F., Yunior, K., \& Novita, H. (2019). "Pengaruh pemagangan dan pelatihan kecakapan hidup terhadap penumbuhan wirausaha baru kota Medan". Jurnal Pemikiran dan Penelitian Administrasi Bisnis dan Kewirausahaan, 4(1). 35-44.

Noor, A.H., (2015). "Pendidikan kecakapan hidup (life skill) di pondok pesantren dalam meningkatkan kemandirian santri”. Jurnal Empowerment, 3(1), 1-31.

Sanjaya. (2008). Kurikulum dan pembelajaran: Teori dan praktik penggembangan KTSP. Jakarta: Penerbit Kencana.

Satori. (2002). "Implementasi life skills dalam konteks pendidikan di sekolah". Journal Pendidikan dan Kebudayaan.

Sihombing. (2000). Pendidikan luar sekolah, kini dan massa depan: Konsep kiat dan pelaksanaan. Jakarta: PD. Mahkota.

Steinberg. (1995). Adolescene. Sanfrancisco: McGraw-Hill Inc.

Sugiyono. (2017). Metode penelitian pendidikan pendekatan kuantitatif, kualitatif, dan $R \& D$. Bandung: Alfabeta.

Sukmadinata, N. S. (2010). Metode penelitian pendidikan. Bandung: PT Remaja Rosdakarya.

Sundari. (2005). Kesehatan mental dalam kehidupan. Jakarta: Rineka Cipta.

Tirtarahardja., \& Sula, S. L. (2000). Pengantar pendidikan. Jakarta: Rineka Cipta.

Undang-undang Republik Indonesia Nomor: 20 Tahun 2003 Tentang Sistem Pendidikan Nasional. 
Jurnal Psikologi Terapan dan Pendidikan

ISSN: $2715-2456$

Vol. 1, No. 2, November 2019, pp. 117-127

Wahyudin, R., \& Rahmawati. (2017). "Penguatan life skills dalam implementasi kurikulum 2013 pada SMA (Sekolah Menengah Atas) di Jawa Barat". Jurnal Indonesia untuk Kajian Pendidikan, 2(1). $1-16$. 